\title{
THE PHENOMENON OF DOUBLE TAXATION AND THE INTERPRETATION OF ARTICLE V (PERMANENT ESTABLISHMENTS) OF THE CANADA-U.S. INCOME TAX CONVENTION (1980)
}

\author{
RACHEL COLABELLA*
}

Double taxation is a phenomenon that arises when two or more states have the jurisdiction to tax the common income of the same person, whether a company or an individual. The author considers the causes and effects of double taxation and then examines bilateral double taxation treaties as an important method of reducing this problem. Double taxation is of growing concern due to the everincreasing international aspects of doing business, which affect both companies and individuals. Ultimately, double taxation impedes the movement of capital, technology, persons and services between states, thus hindering lasting economic cooperation.

The history of double taxation treaties, some model treaties and finally the 1980 Canada-U.S. Convention are discussed. The writer closely examines the Permanent Establishment provision in the Convention. The concept of a Permanent Establishment is central to the Canada-U.S. Convention, as it is the mechanism by which a resident of one state can be taxed by the other state. The business profits of a resident can only be taxed by the other state if that resident carried on business through a Permanent Establishment in the other state.

Drawing on Canadian, U.S. and international taxation treaty interpretations, the author outlines the comprehensive test for determining the existence of a Permanent Establishment. Building on this analysis, she discusses the practical tax planning problem of whether to conduct business in foreign States through Permanent Establishments or through some other entities. Finally, the writer discusses both the advantages and disadvantages of the current Permanent Establishment provision and its effect on trade between Canada and the U.S.
La double imposition est un phénomène qui survient quand le revenu commun d'une même personne - individu ou société - est imposé par plusieurs autorités fiscales. L'auteure étudie les causes et effets de la double imposition et examine les traités bilatéraux comme présentant un moyen efficace de réduire ce problème. Pour les particuliers comme pour les sociétés, la double imposition est une préoccupation croissante compte tenu de la mondialisation des affaires. Ultimement, elle fait obstacle à la circulation des capitaux, de la technologie, des personnes et des services entre États, freinant ainsi une coopération économique durable.

Le présent article se penche sur l'histoire des traités relatifs à cette question, sur des traités modèles et enfin sur la Convention de 1980 entre le Canada et les États-Unis. L'auteure examine de près la disposition relative à l'établissement stable. Ce principe est au caur mème de la Convention entre les deux pays, puisqu'il autorise le résident d'un État donné à faire l'objet de deux prélèvements d'impôt. Seule la disposition relative ì l'établissement stable autorise un autre État $\dot{a}$ percevoir des impôts sur les bénéfices industriels et commerciaux réalisés par le résident en question.

En s'inspirant de diverses interprétations de traités canadiens, américains et internationaux sur la question, l'auteure décrit une façon détaillée d'établir l'existence d'un établissement stable. Elle discute ensuite du probleme fiscal pratique qui incite à faire affaire grâce aux établissements stables ou par d'autres moyens. Finalement, l'auteure discute des avantages et des inconvénients de la disposition actuelle concernant l'établissement stable et son effet sur le commerce canadoaméricain.

\section{TABLE OF CONTENTS}

I. INTRODUCTION

II. CAUSES AND CONSEQUENCES OF DOUBLE TAXATION $\ldots \ldots \ldots \ldots \ldots \ldots \ldots \ldots$

- Second year law student at the University of Alberta. This article won second prize in the general category of the 1995 William Morrow essay contest. 
responsibility of every man and woman." ${ }^{98}$ This statement confirms the need for the psychiatrist to look at the political and societal consequences when Prozac is used to transform the personalities of "normal" individuals. Of specific consequence to this type of use is section 7 of the Declaration, which reads, in part: "The psychiatrist must on no account utilize the tools of his profession, once the absence of psychiatric illness has been established." 99 From this then, the psychiatrist would either have to define Prozac as not being a tool of his or her profession - a difficult argument to make - or would have to find a psychiatric illness where one does not exist in order to prescribe Prozac to a patient who is well.

\section{CONCLUSION}

"[With the perfection of mood brighteners], we begin to transform not just how we are responding but who we are. I have seen too much of the suffering that depression brings to argue against travelling further down that path. But I wonder where it will take us." ${ }^{100}$ Prozac has provided many millions of people with relief from the symptoms of their psychiatric illnesses. If its use in society ended there, there would be few disturbing ethical implications. However, due to the use of Prozac to bring about socially desirable personality changes, we are instead left to question the very nature of self. What is the true nature of self; the personality before or after the medication? Ought we to mute all negative emotions? Does Prozac really make us "better"? Add to these troubling questions the uncertain side and long term effects of the drug in the general population, and psychiatrists are left tossing on a murky ethical sea without a rudder. Seemingly, the codes of ethics counsel against such use of a psychopharmaceutical, but these codes were drafted when Prozac was a matter of science fiction, not scientific fact. The psychiatrist is instead forced to examine each case individually, weighing questions of patient autonomy, risk and societal interests. In most cases, the balance would favour not prescribing Prozac to the normal patient. However, this suggestion may have been rendered merely academic by events; the genie is out of the bottle. Thus, the best course for the psychiatric community to take at this point is to encourage public debate on the ethical questions relating to Prozac and its unlabelled use, as well as public education about its possible health risks. Psychiatrists and other physicians cannot predict the specific path that this drug will take us down, but perhaps informed public debate can highlight some of the forks in that path. 


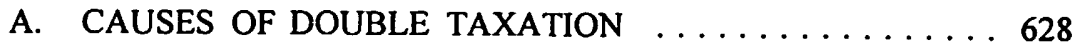

B. CONSEQUENCES OF DOUBLE TAXATION .......6 629

III. DEVELOPMENT OF DOUBLE

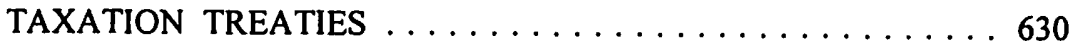

A. HISTORY OF DOUBLE

B. MODEL TAX TREATIES $\ldots \ldots \ldots \ldots \ldots \ldots \ldots \ldots 630$

C. CANADA-U.S. INCOME TAX

CONVENTION (1980) . . . . . . . . . . . . . 632

VI. ARTICLE V - "PERMANENT ESTABLISHMENT":

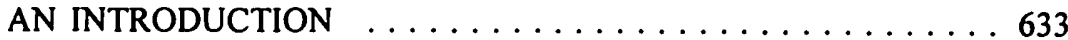

A. DEFINITION OF "PERMANENT

B. HISTORY OF THE PE CONCEPT . . . . . . . . . 633

V. SOURCES AND PRINCIPLES OF TAX TREATY

INTERPRETATION . . . . . . . . . . . . . . . . 634

VI. DETERMINING THE EXISTENCE OF A PE . . . . . . . 637

A. THE OBJECTIVE PRESENCE OF THE PE . . . . . . 637

B. THE SUBJECTIVE PRESENCE OF THE PE . . . . . . 640

C. THE FUNCTIONALITY OF THE PE . . . . . . . . . . 644

VII. TAX PLANNING CONSIDERATIONS: BRANCH

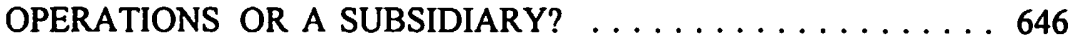

VIII. CONCLUSION: ADEQUACY OF THE PE

PROVISIONS IN THE PREVENTION OF

DOUBLE TAXATION .................6 648

\section{INTRODUCTION}

Double taxation is a recent phenomenon that first appeared in the late nineteenth century' and has since significantly impacted international business transactions. Double taxation occurs when the income of the same taxable person, whether an individual, a company or other body of persons, ${ }^{2}$ is taxed by more than one state having the jurisdiction to tax that income. This article will examine the causes of double taxation as well its detrimental consequences. The article will then outline the history of the creation of bilateral double taxation treaties as one method designed to eliminate the incidence of double taxation, with particular emphasis on the Canada-U.S. Convention. ${ }^{3}$ The article's primary focus will be on the interpretation of one particular aspect of the Convention - namely, the allocation of taxing jurisdiction over permanent establishments as interpreted by Canadian, American and international case law as well as other sources of tax treaty interpretation. The advantages and

M.B. Carroll, "The Historical Development of Income Tax Treaties" in J.E. Bischel, ed., Income Tax Treaties (New York City: Practising Law Institute, 1978) 51 at 52.

Infra note 3 at art. III(I)(e).

Convention between Canada and the United States of America with Respect to Taxes on Income and on Capital (With Exchange of Notes), 26 September 1980, Can.T.S. 1984 No. 15 (hereinafter Canada-U.S. Convention or the Convention] (entered into force 16 August 1984). 
disadvantages of setting up a permanent establishment in one of the Contracting States as opposed to conducting other modes of business will then be evaluated. Finally, the article will consider the permanent establishment clause as a method of allocating taxing jurisdiction between the Contracting States to the Convention, given the present economic relationship between Canada and the United States.

\section{CAUSES AND CONSEQUENCES OF DOUBLE TAXATION}

\section{A. CAUSES OF DOUBLE TAXATION}

The main cause of double taxation is the internationalization of the economy. ${ }^{4}$ Over the last century, communication, transportation and other forms of technology have significantly improved. ${ }^{3}$ Because of this, companies have been able to set up operations in other countries in the search for new markets to promote their products where there may be relatively cheap labour or raw materials or other advantages available. ${ }^{6}$ In addition, individuals have become more mobile on a permanent and temporary basis in either the search for "a better standard of living, working conditions and earnings than in their own countries...,"7 or in the course of being transferred by employers "to develop or serve an existing market." ${ }^{8}$ Given these facts, companies and individuals may be required to pay tax to more than one state on the same earned income.

Other factors causing double taxation are the existence of complex and conflicting tax principles, the different definitions given to the same element in taxation, ${ }^{9}$ and the different ways of computing taxable income between different countries. ${ }^{10}$ For example, in Canada, residency is the basis for taxation, "whereas in the United States, citizenship is the basis for taxation. ${ }^{12}$ Thus, where an American citizen resides in Canada, it is possible that the worldwide income of that individual will be taxed by both Canada and the United States. ${ }^{13}$ This reflects the fact that an aspect of a state's sovereignty is the power to impose taxes over its subjects in any manner it sees fit. ${ }^{14}$ Thus, where more than one state is entitled to apply its tax laws to the same set of facts, double taxation is bound to arise..$^{\text {is }}$

10 Pires, supra note 4 at 67.

11

Ibid. at 3.

Ibid. at 4, 65-66.

Ibid. at 3.

Ibid. 3.

Pires, supra note 4 at 67. Ibid. at 141.

M. Pires, International Juridical Double Taxation of Income (Deventer, The Netherlands: Kluwer Law and Taxation Publishers, 1989) at 65-66.

For example, the definition of "business" in art. V(1) of the Canada-U.S. Convention, supra note

Income Tax Act, R.S.C. 1985 (5th Supp.), c. 1, s. 2(1).

The United States is hereinafter referred to as the U.S.

R.S.J. Martha, The Jurisdiction to Tax in International Law - Theory and Practice of Legislative Fiscal Jurisdiction (Deventer, The Netherlands: Kluwer Law and Taxation Publishers, 1989) at 43. 
A final factor causing double taxation is the increasing levels of taxation in many states. ${ }^{16}$ For example, when Canada published its first income tax legislation in 1917, the legislation was only ten pages in length, ${ }^{17}$ reflecting the fact that very few items of income were considered taxable. Canada's Income Tax Act has expanded considerably in length over the years and presently reflects a vast number of items that are considered to be income for tax purposes. ${ }^{18}$ The same is also true of other states ${ }^{19}$ whose governments view their powers of taxation as an important means of raising revenues to meet various national objectives. Given this, there will likely be some overlap where a person is earning income in more than one country.

\section{B. CONSEQUENCES OF DOUBLE TAXATION}

Double taxation is a concern in international business because of its detrimental consequences. With respect to economic consequences, "[d]ouble taxation affects both the movement of capital and persons as well as the transfer of technology and exchange of services between different states,"120 thus hindering the establishment of lasting economic co-operation between states. With respect to financial consequences, a state may not receive tax revenues to which it is otherwise entitled where a taxpayer evades or avoids taxation, ${ }^{21}$ or simply does not fit the preconditions which give rise to taxation. ${ }^{22}$ Where a state does not receive such tax revenues, the state may have difficulties in providing services and creating various national programs for the benefit of its citizens, thereby resulting in socio-political consequences. ${ }^{23}$ Finally, double taxation has cultural consequences in that it can inhibit certain taxpayers, such as scientists, artists and athletes, from engaging in activities to improve their country's cultural base. ${ }^{24}$

Pires, supra note 4 at 72.

J. Denhamer, A Study Guide: An Introduction to Taxation in Canada (Calgary: University of Calgary, 1992) at 2-1.

Supra note 11 .

E.g., Internal Revenue Code of the U.S., cited in CCH Tax Law Editors, U.S. Master Tax Guide, 77th ed. (Chicago: Commerce Clearing House, Inc., 1993) [hereinafter Internal Revenue Code].

Pires, supra note 4 at 75 .

Tax evasion differs from tax avoidance under Canadian income tax laws in that (a) it is illegal, (b) a taxpayer would be criminally responsible for evasion, (c) there are significantly higher penalties and (d) it is extremely difficult to prove. No specific provisions in the Income Tax Act, supra note 11 define these terms. However, the case law suggests that if a taxpayer engages in tax avoidance by arranging his or her affairs in such a way so as to reduce the payment of tax, the courts will simply rewrite the transaction to ensure the taxpayer pays the required tax (see Keiboom v. M.N.R., [1992] 2 C.T.C. 59 (F.C.A.)). Tax evasion, on the other hand, is where a taxpayer wilfully and deliberately conducts activities to prevent the payment of tax, such as the destruction or concealment of documents which should be available to the Department of Revenue for determining the taxes of the taxpayer in a given year (see Matthys v. $R$, [1986] 2 C.T.C. 307 (Ont. Dist. Ct.)). Thus, tax evasion has a much higher threshold than tax avoidance.

Pires, supra note 4 at 86 .

Ibid. at 89.

Ibid. 


\section{DEVELOPMENT OF DOUBLE TAXATION TREATIES}

\section{A. HISTORY OF DOUBLE TAXATION TREATIES}

As one attempt to lessen the incidence of double taxation, a number of countries have entered into bilateral double taxation treaties. The first treaty for the avoidance of double taxation of income and property was signed on June 21, 1899 between AustriaHungary and Prussia. ${ }^{25}$ This treaty was followed by a number of bilateral double taxation treaties between various states in Central Europe. Although these treaties were terminated by the hostilities of World War $\mathrm{I}^{26}$ the number of bilateral double taxation treaties increased significantly after that conflict. Specifically, between 1922 and 1939, sixty-nine treaties were signed between various states. ${ }^{27}$ These treaties were concluded mainly between countries in Central and Northern Europe and North America, reflecting the major trade relationships in the world at that time. As world trade networks expanded, states in other geographical locations also became involved in the conclusion of double taxation treaties. ${ }^{28}$ "At present, states on all continents are involved in this movement." ${ }^{29}$

Each of these treaties was designed to reduce the incidence of double taxation through the creation of uniform tax criteria to be applied by the Contracting States. The treaties served to allocate taxing jurisdiction by establishing "the limits within which [C]ontracting States [could] apply their tax law so as to avoid [any] overlap...." These treaties also had several indirect purposes, including "protecting the taxpayer; ... attracting investment to less developed countries; ... facilitating the expansion of companies from the developed countries; ... [and] fostering other types of relations between States in addition to economic ones." ${ }^{31}$

\section{B. MODEL TAX TREATIES}

The first attempt at the creation of a model tax treaty was in 1928 by the League of Nations. ${ }^{32}$ The League adopted four model treaties at the urging of the International Chamber of Commerce, which was concerned with resuming international business and investment that had been severely hindered by high tax rates following World War I. ${ }^{33}$ A further model convention was drafted in 1943 in Mexico and again in 1946 in

\footnotetext{
2s Carroll, supra note 1.

$26 \quad$ Ibid. at 53.

27 Pires, supra note 4 at $95-96$.

$28 \quad$ Ibid. at 96.

29 lbid.

$30 \quad$ Ibid. at 214

1 lbid. at 214-15.

32 K. Vogel, "Double Tax Treaties and Their Interpretation" (1986) 4 Int'l Tax \& Bus. Lawyer 4 at 10-11.

33 Carroll, supra note 1 at 53; see also A.A. Skaar, Permanent Establishment - Erosion of a Tax Treaty Principle (Deventer, The Netherlands: Kluwer Law and Taxation Publishers, 1991) at 77.
} 
London $^{34}$ to foster and improve trade relations between developing countries and developed countries. ${ }^{35}$

Following World War II, the Organization for European Economic Co-operation [hereinafter the OEEC] was formed to facilitate trade relations between North American and European states. ${ }^{36}$ As stated in the Report of the OECD Committee on Fiscal Affairs:

\begin{abstract}
The increasing economic interdependence of the Member countries of the OEEC in the post-war period and the economic co-operation established among them showed increasingly clearly the importance of measures for preventing international double taxation. The need was recognised for extending the network of bilateral double taxation conventions to all Member countries of the OEEC, and subsequently of the OECD [Organization for Economic Co-operation and Development], several of which had so far concluded only very few conventions and some none at all. At the same time, hamonization of these conventions in accordance with uniform principles, definitions, rules and methods, and agreement on a common interpretation, became increasingly desirable. ${ }^{37}$
\end{abstract}

As a result of this, the Fiscal Committee of the Organization for Economic Cooperation and Development [hereinafter the OECD] published several reports between 1958 and 1961 regarding the elimination of double taxation, and based on these reports, published its first model treaty in $1963 .^{38}$ In 1977 , it was replaced by another model treaty because of "changes in systems of taxation, ... the increase in international fiscal relations, ... the development of new sectors of business activity and the increasingly complex forms of organization adopted by enterprises for their international activities." ${ }^{39}$ This 1977 model treaty was amended again in 1992 by the OECD, and presently serves as a guideline to OECD member countries for the creation of bilateral tax treaties. ${ }^{40}$ Most bilateral tax conventions concluded between member countries are based on the 1977 model as amended in $1992 . .^{41}$

OECD, Committee on Fiscal Affairs, Model Double Taxation Convention on Income and on Capital (Paris: OECD, 1977) at 7.

Carroll, supra note 1 at 56.

Skaar, supra note 33 at 96 .

OECD, Committee on Fiscal Affairs, supra note 34.

Vogel, supra note 32 at 11 ; see also Carroll, supra note 1 at 59; and OECD, Committee on Fiscal Affairs, supra note 34 at 8 . This 1963 model treaty was entitled "Draft Double Taxation Convention on Income and Capital."

OECD, Committee on Fiscal Affairs, ibid.

B.G. Broadhurst, "Revisions to the OECD Model Convention" (1992) 40 Can. Tax J. 1347. Although the 1977 Model treaty was amended in 1992, this article will focus primarily on the provisions of the 1977 treaty [hereinafter the 1977 OECD Model Treaty, supra note 34] since the Canada-U.S. Convention is based on this model. Also note that the 1992 amendments did not affect the PE provisions of the 1977 OECD Model Treaty except with respect to changing the numbering of some of the paragraphs. The paragraph numbering used in the 1977 OECD Model Treaty will be referred to throughout this article.

Skaar, supra note 33 at 99. 


\section{CANADA-U.S. INCOME TAX CONVENTION (1980)}

Based on the 1977 OECD Model Treaty, Canada and the U.S. entered into a Convention in $1980 .{ }^{42}$ This treaty presently governs tax relations between Canada and the U.S. The Convention was signed at Washington on September 26, 1980 and was amended by two Protocols signed on June 14, 1983 and March 28, 1984. ${ }^{43}$ The treaty was brought into force on August 16, 1984 when the Contracting States exchanged instruments of ratification. ${ }^{44}$ This Convention replaces an earlier treaty concerning double taxation which was entered into by Canada and the U.S. in 1942.45

The purpose of the Canada-U.S. Convention is to avoid double taxation on the income of citizens and residents of the Contracting States. ${ }^{46}$ For example, as mentioned earlier, in the U.S., all American citizens are required to pay tax on their worldwide income even if they are resident in another state. ${ }^{47}$ In Canada, any individual who is resident in Canada in a given taxation year is taxed on his or her worldwide income. ${ }^{48}$ Thus one does not have to be a Canadian citizen to be taxed by Canadian taxing authorities. American and Canadian methods of taxing their subjects clearly create significant overlap between the two bodies of law, thus giving rise to double taxation. It is this double taxation that the treaty is designed to eliminate.

Another purpose of the Canada-U.S. Convention is to prevent fiscal evasion of the income taxes of the two Contracting States. ${ }^{49} \mathrm{~A}$ final purpose is "to promote close economic cooperation between the two countries and to eliminate possible barriers to trade caused by overlapping taxing jurisdictions of the two countries." ${ }^{150}$ This is especially important given the "free trade" economic relationship between Canada and the U.S.'

Canada-U.S. Convention, supra note 3. The wording of this Convention is virtually identical to that of the 1977 OECD Model Treaty; see Carroll, supra note 1 at 59.

43 M. Abrutyn \& N. Boidman, "The New Canada-United States Tax Convention" (1986) 20:1 Int'1 Lawyer 125 at 126.

$4 \quad$ Ibid.

4 Canada-U.S. Convention and Protocol for the Avoidance of Double Taxation and the Prevention of Fiscal Evasion in the Case of Income Taxes, 4 March 1942, Can. T.S. 1942 No. 2 [hereinafter the 1942 Convention].

46 Canada-U.S. Convention, supra note 3, preamble.

47 Internal Revenue Code, supra note 19, para. 109.

48 Income Tax Act, supra note 11, s.2(1), s.250.

49 M.J. Langer, "The New Canada-United States Income Tax Treaty: Some Significant Differences Between the Old and New Treaties" in M.J. Langer, Chairman, The New Canada-United States Income Tax Treaty (USA: Practising Law Institute, 1984) 9 at 52.

5t This relationship is governed by the Canada-United States Free Trade Agreement, 22 December 1987, Can.T.S. 1989 No. 3, 27 I.L.M. 281 [hereinafter Free Trade Agreement] (Part A, Schedule to the Canada-United States Free Trade Agreement Implementation Act, S.C. 1988, c. 65). 


\section{ARTICLE V - "PERMANENT ESTABLISHMENT": AN INTRODUCTION}

\section{A. DEFINITION OF "PERMANENT ESTABLISHMENT"}

The purpose of this article is to focus on one particular rule in the Canada-U.S. Convention which allocates taxing jurisdiction between Canada and the U.S. - namely, the taxation of a "permanent establishment" [hereinafter PE]. The PE concept is the main instrument in the Canada-U.S. Convention for establishing the jurisdiction of a Contracting State to tax profits from the unincorporated business activities of an enterprise of the other Contracting State. ${ }^{52}$

The definition of PE contained in article $\mathrm{V}$ of the Canada-U.S. Convention ${ }^{53}$ is "a fixed place of business through which the business of a resident of a Contracting State is wholly or partly carried on." ${ }^{54}$ This definition is known as the basic rule for PE. ${ }^{55}$ The balance of this article will focus on how this basic rule for PE in the Canada-U.S. Convention has been interpreted. To determine what is or might be included in the definition of PE, both Canadian and American judicial findings and other sources of interpretation will be examined. It is important to know if a PE exists in one of the Contracting States because under article VII of the Canada-U.S. Convention, the

\footnotetext{
business profits of a resident of a Contracting State shall be taxable only in that State unless the resident carries on business in the other Contracting State through a [PE] situated therein. If the resident carries on, or has carried on, business as aforesaid, the business profits of the resident may be taxed in the other State, but only so much of them as is attributable to that [PE].6
}

Thus, the PE concept is extremely important in preventing the incidence of double taxation between Canada and the United States.

\section{B. HISTORY OF THE PE CONCEPT}

In order to understand how the PE concept has been interpreted and why it has been interpreted in that way, it is important to understand under what circumstances the PE concept emerged. The PE concept first appeared in Prussian law and in the law of the German empire between 1845 and $1909 .{ }^{57}$ It was originally designed to regulate the conduct of business activities between Contracting States. The PE concept was later used as a method of allocating tax jurisdiction when many states entered into bilateral double taxation treaties following World War $\mathrm{I}^{58}$ At that time, production was

Skaar, supra note 33 at 1; see also J.P. Fuller, "The New U.S.-Canada Income Tax Treaty: Permanent Establishment and Business Profits Rules" in M.J. Langer, chairman, supra note 49, 335 at 337.

The wording is very similar to that in Article V of 1977 OECD Model Treaty.

Canada-U.S. Comvention, supra note 3 , art. V.

Skaar, supra note 33 at 11.

Canada-U.S. Convention, supra note 3, art. VII(1); see also Fuller, supra note 52 at 337.

Skaar, supra note 33 at 73.

Ibid. at 77. 
relatively immobile; the capital of industrialized countries was mainly invested in plants and machines, and therefore, was relatively fixed and permanent in nature. Because of improved transportation, international trade increased and companies began seeing the advantages of establishing permanent locations in host countries. As stated by Skaar, "international business extensive enough to benefit from a foreign country's organization of labor forces and real capital located there required the maintenance of an establishment in the [foreign] country." ${ }^{59}$ Thus, the definition of a PE requiring a "fixed place of business" was formulated in various double taxation treaties ${ }^{60}$ as a reflection of these conditions.

In recent years, however, production factors have become even more mobile; companies do not have to relocate to another country to perform economically significant operations and workers do not have to move to the foreign country permanently. Canadian, American and international judicial interpretation of the basic rule for PE has tried to take account of these changing conditions, even though, as this article will illustrate, the basic definition of $\mathrm{PE}$ has remained the same. This interpretation has sparked a debate over the need to change the treaty definition of a PE to reflect modern economic relationships. ${ }^{61}$

\section{SOURCES AND PRINCIPLES OF TAX TREATY INTERPRETATION}

Several sources can be examined to determine what items would be included or excluded in the basic rule for PE under the Canada-U.S. Convention. The first source is the basic definition of PE under the Convention itself and any amendments made to the treaty from the 1942 Convention. ${ }^{62}$ Unfortunately, the definition of PE under the Canada-U.S. Convention contains many unanswered questions. For example, PE is defined using terms such as "business," which are not defined in the treaty.

The Vienna Convention on the Law of Treaties ${ }^{63}$ can be an aid to interpreting undefined terms in the PE definition under the Canada-U.S. Convention. Article 31(1) of the Vienna Convention states that "a treaty shall be interpreted in good faith in accordance with the ordinary meaning to be given to the terms of the treaty in their context and in the light of its object and purpose." ${ }^{64}$ Thus, to interpret the basic rule

Ibid. at 67.

Including the 1942 Canada-U.S. Convention and later, the 1980 Convention.

This debate will be discussed in the conclusion of this article.

Skaar, supra note 33 at 40 . It should be kept in mind that the Canada-U.S. Convention, as a source of international law, is not an ordinary statute, and thus, should not be construed in the strict manner that the tax legislation of Canada and the U.S. is construed. Rather, because the Convention is a contract between two sovereign states, it should be interpreted using other means. See D.A. Ward, "Principles To Be Applied in Interpreting Tax Treaties" (1977) 25 Can. Tax J. 263 at 263-64.

63 UNGAOR Doc. AVCONF. $39 / 27$ (23 May 1969), 8 I.L.M. 679 [hereinafter Vienna Convention] (entered into force on 27 January 1980). The creation and consequences of the Canada-U.S. Convention are to be determined according to the rules contained in the Vienna Convention. This is because the Canada-U.S. Convention is an international agreement and because Canada and the U.S. are signatories to the Vienna Convention - Vogel, supra note 32 at 15.

Ibid. [emphasis added]. 
for PE, one must look at the intention behind the provision to find the ordinary meaning of the text. In addition, one must give "the widest scope to the language in order to include within it all matters intended to be included," ${ }^{\text {"6s }}$ and must read the basic rule as a whole within the context of the entire PE provisions under article $\mathrm{V}$ of the Canada-U.S. Convention. ${ }^{66}$

Articles 31(3), (4) and 32 of the Vienna Convention state that to determine the ordinary meaning of a particular provision, one can take into account any agreement made between the two states relating to the treaty, any agreement made or practice established by the Contracting parties and any relevant rules of international law or other supplementary means of interpretation. Thus, in interpreting the basic rule for PE under the Canada-U.S. Convention, resort can be had to any protocols, observations and reservations made by the Contracting parties for the conclusion of the treaty. ${ }^{67}$ In addition, the Technical Explanation under the Canada-U.S. Convention ${ }^{68}$ as well as any mutual agreements made between Canada and the U.S. ${ }^{69}$ can be considered in the interpretation of the basic rule for PE. ${ }^{70}$

Where the "ordinary meaning of the words is ambiguous or leads to an unreasonable result, [one] should resort to other techniques of interpretation to discover what the parties intended." ${ }^{71}$ Article 31(4) of the Vienna Convention states that "a special meaning shall be given to a term if it is established that the parties so intended." 72 This implies that when needed, one can look to meanings given to the terms of the PE provisions under Canadian and American statutory law and judicial interpretation as well as supporting authorities. ${ }^{73}$ Where these sources of domestic law have been resorted to in precedent as a means of interpreting the basic rule for PE under the Canada-U.S. Convention, the Canadian Tax Appeal Board has tried to interpret the

Ward, supra note 62 at 265 , referring to Shahmoon v. M.N.R., [1975] C.T.C. 2361 (Tax Rev. Bd.) [hereinafter Shahmoon].

Ward, ibid.

Skaar, supra note 33 at $\mathbf{4 4 - 4 5}$.

Infra note 82.

Any mutual agreement would be made under the Mutual Agreement Procedure, art. XXVI of the Canada-U.S. Convention, supra note 3.

Ward, supra note 62 at 270.

Ibid. at 266.

This is also the case under article III(2) of the Canada-U.S. Convention, supra note 3 which states:

As regards the application of the Convention by a Contracting State any term not defined therein shall, unless the context otherwise requires and subject to the provisions of Article XXVI (Mutual Agreement Procedure), have the meaning which it has under the law of that State concerning the taxes to which the Convention applies.

With respect to supporting authorities, in the U.S., one can look to Revenue Rulings which are a binding source of law (Skaar, supra note 33 at 56-57) and Private Letter Rulings which are not binding but are helpful in determining the position of the Internal Revenue Service on a particular tax issue (J.P. Holden \& M.S. Novey, "Legitimate Uses of Letter Rulings Issued to Other Taxpayers - A Reply to Gerald Portney" (1984) 37 Tax Lawyer 337 at 348). In Canada, Interpretation Bulletins can also be used to predict the position of the Minister of National Revenue on a particular tax issue, although this is not a binding source of law (Ladin v. M.N.R., [1977] C.T.C. 2604 (Tax Rev. Bd.)). 
Convention in a manner consistent with American courts on the same issue. ${ }^{74}$ The same is also true of American courts with respect to Canadian judicial decisions. ${ }^{75}$

When using domestic law as a source of interpretation, it must be kept in mind that treaty law is supreme to domestic law. ${ }^{76}$ In addition, when referring to domestic laws, an ambulatory interpretation generally should be used as opposed to a static interpretation." In other words, the domestic laws at the time the tax case arises should be used rather than the domestic laws at the time the Canada-U.S. Convention was concluded. ${ }^{78}$

Resort to domestic laws can still be troublesome, however, where the domestic laws of Canada and the U.S. conflict in the interpretation of a term in the basic rule for PE. Thus, final resort can also be had to the 1977 OECD Model Treaty and its commentaries since the Canada-U.S. Convention is based on this model. ${ }^{79}$ In addition, one can look to judicial rulings of other states which have interpreted the PE provisions in treaties based on the 1977 OECD Model Treaty. Although not binding, these are persuasive sources for determining what might be included in the PE concept under the Canada-U.S. Convention. ${ }^{80}$

In determining what is and what can be included under the basic rule for PE under the Canada-U.S. Convention, this article will focus primarily on the treaty itself and the Technical Explanation contained therein, as well as Canadian and American statutory and common law. ${ }^{81}$ Where these sources do not provide a sufficient explanation as to when a PE should be found to exist, the article will also consider the 1977 OECD Model Treaty and its commentaries, academic literature and international judicial and administrative rulings that interpret other OECD-based treaties. These latter sources can be persuasive in determining what should be included in the PE concept.

Number 630 v. M.N.R. (1959), 59 D.T.C. 300 at 303 (Tax App. Bd.); Canadian Pacific Lid. v. $R$ (1976), 76 D.T.C. 6120 at 6135 (Tax App. Bd.).

Donroy, Lid. v. United States, 301 F.2d 200 (9th Cir. 1962).

Vogel, supra note 32 at 20.

Skaar, supra note 33 at 54-55.

Due to some controversy surrounding this issue in R. v. Melford Developments Inc., [1982] C.T.C. 330 (S.C.C.), where the Supreme Court of Canada favoured the static interpretation, section 3 of the Canadian Income Tax Conventions Interpretation Act, R.S.C. 1985, c.I-4 was passed and states that the ambulatory interpretation should be used. This method of interpretation is also favoured by the U.S. Tax Court and the Internal Revenue Service - see IRS in Revenue Ruling 79-56 1979-1 C.B. 459 and Estate of Burghardt v. Comm'r, 80 T.C. 705 (1983), aff'd 734 F.2d 3 (1984) (both referred to in Skaar, supra note 33 at 54). Skaar, ibid. at 60-61.

Note, however, that the OECD Commentaries are not necessarily considered decisive for interpretation of Canadian treaty obligations - see R.A. Short, "Comment" (Address to the ThirtySecond Tax Conference, 25 November 1980) in Canadian Tax Foundation, Report of Proceedings of the Thirty-Second Tax Conference (Canada: C.T.F., 1980) at 350, where Alan Short, former Director of Revenue Canada, was reluctant to accept the OECD Commentaries as binding on Canada. Contra R.G. Tremblay \& H.A. Garnett, The New Canada-U.S. Tax Convention (Scarborough: Prentice-Hall Canada Inc., 1985) at 3. 


\section{DETERMINING THE EXISTENCE OF A PE}

Under the Canada-U.S. Convention, a PE is a "fixed place of business through which the business of a resident of a Contracting State is wholly or partly carried on. ${ }^{182}$ Skaar concludes that this basic rule is made up of three tests which must be satisfied before a PE can be found to exist in a Contracting State. ${ }^{83}$ The first test is the objective, physical presence of the PE in one of the Contracting States: there must be a place of business in a Contracting State and that place of business must be located at a specific place ${ }^{84}$ The second test is the subjective presence of the PE: there must be a right to use the place of business and the right to use the place of business must be permanent. ${ }^{85}$ The final test is the functionality of the PE: the PE must undertake a "business" activity and this business activity must be performed through the place of business. ${ }^{86}$ Skaar's formulation of these three tests is based on an examination of the commentaries to the 1977 OECD Model Treaty ${ }^{87}$ and of international judicial findings concerning various OECD-based double taxation treaties. This article will examine these three tests in the context of the Canada-U.S. Convention.

\section{A. THE OBJECTIVE PRESENCE OF THE PE}

To satisfy the objective presence test, there must be a place of business in one of the Contracting States to the Canada-U.S. Convention, and this place of business must be located at a specific place. If these tests are met, that part of the definition of a PE under article V(1) of the Canada-U.S. Convention which requires the PE to be a "fixed place of business" is satisfied.

Supra note 3, art. V(1). Note that under article V(1) of the 1977 OECD Model Treaty, supra note 34 , a PE is defined as a "fixed place of business through which the business of an enterprise is wholly or partly carried on" [emphasis added]. The term "enterprise" used to be included in the 1942 Canada-U.S. Convention. It has been replaced in the 1980 Convention with the term "resident" to avoid introducing an additional term into the Convention - see The New CanadaU.S. Tax Treaty with Technical Explanation, 1st ed. (Don Mills: CCH Canadian Ltd., 1984) at 5 [hereinafter Technical Explanation]. This provides a lower threshold to be proved; i.e. "a corporation need show only that it is incorporated in the [U.S.] in order to qualify for the business profit rules [under article VII of the Convention], and not that it is also engaged in an enterprise in the [U.S.]. The same would be true of a Canadian resident company seeking the benefits of the limited right of the U.S. to tax its business profits." See Coopers \& Lybrand, The New CanadaU.S. Tax Treaty: Impact on Corporations and Individuals (Canada: CCH Canadian Ltd., 1985) at 15-16.

83 Supra note 33 at 106.

a Ibid.

as Ibid. at 106-107.

s6 Ibid. at 107.

871977 OECD Model Treaty, Commentary on Article V(1), supra note 34 at 59 states that a PE is determined by the following tests: "the existence of a 'place of business'; ... this place of business must be 'fixed'; ... [and] the carrying on of the business of the enterprise through this fixed place of business." 


\section{The Place of Business Test}

Although "place of business" is not defined in the Canada-U.S. Convention, article $\mathrm{V}(2)$ of the Convention lists specific places of business that are to be considered PEs. These include "(a) A place of management; (b) A branch; (c) An office; (d) A factory; (e) A workshop; and (f) A mine, an oil or gas well, a quarry or any other place of extraction of natural resources." This list provides examples of what can be considered a PE, but it is not exhaustive. ${ }^{88}$ Thus, whether or not a particular place is a "place of business" can be determined by having regard to the examples provided in this list. However, as stated by Skaar, "[although this] 'positive list' may support the inclusion of a certain place as a PE-constituting 'place of business,' ... it cannot be used to exclude places which are not of a similar nature as the places mentioned in the 'positive list." "89 It should also be noted that this list of PE-constituting "places of business" may be overruled by the items under article V(6) of the Canada-U.S. Convention which are expressly not to be considered PEs by virtue of the nature of the activities conducted there.

The example "places of business" listed under article V(2) of the Canada-U.S. Convention are not defined in the treaty, and thus, the OECD commentaries, academia and case law must be considered as sources to interpret what these various "places of business" might include. For example, Skaar defines a "branch" as a "legally dependent part of the enterprise, with a certain commercial independence." ${ }^{90}$ However, as long as the branch has an office, it will constitute a PE under article $\mathrm{V}(2)(\mathrm{c})$ of the Convention, even though that office has no commercial independence. In addition, a "place of management" is not necessarily an "office." This is why it is mentioned separately under article V(2) of the Canada-U.S. Convention. ${ }^{91}$ To be a "place of management," Skaar states that a place does not have to be the head office of a corporation but it must have the power to make significant decisions as opposed to merely carrying out the instructions of head office. ${ }^{92}$ This conclusion is also supported by the British decision in Borgny Dolphin, ${ }^{93}$ and is thus a persuasive conclusion with respect to the Canada-U.S. Convention. Finally, "any other place of extraction of natural resources" should be interpreted broadly according to the OECD Commentaries. ${ }^{94}$ Therefore, "other places for extraction of natural resources do not have to be similar to the examples listed. Such places may constitute a 'place of business' whether they contain hydrocarbons, metallic objects or other natural resources."195

1977 OECD Model Treaty, Commentary on art. V(2), supra note 34 at 61.

Skaar, supra note 33 at 114.

Ibid. at 116.

1977 OECD Model Treaty, Commentary on art. V(2), supra note 34 at 61.

Supra note 33 at 117.

(6 December 1984), (Special Commissioners of Income Tax) [unreported]. Referred to in Skaar, ibid.

1977 OECD Model Treaty, supra note 34 at 61-62.

Nitikman, "The Meaning of Permanent Establishment in the 1981 U.S. Model Income Tax Treaty"

(1989) 15 Int'1 Tax J. 159 at 172, cited in Skaar, supra note 33 at 118-19. 
There are some items that specifically should not be considered "places of business" under the basic rule for PE in the Canada-U.S. Convention. For example, substantial machinery or equipment has specifically been excluded as a deemed PE under the 1980 Canada-U.S. Convention even though it was included in the 1942 Convention. ${ }^{96}$ Given this, substantial machinery or equipment would only be considered a PE if it passed all of the tests outlined by Skaar; it is not automatically deemed to be a PE.

In addition, where a person's assets in another country consist solely of securities and bank accounts, these assets are not considered "places of business" unless they meet the other tests outlined in this article. ${ }^{97}$ In M.N.R. v. Tara Exploration and Development Company Limited, ${ }^{98}$ the Supreme Court of Canada held that a PE did not exist in a foreign company's bank account in Canada solely by virtue of the existence of the bank account. The same line of thinking was followed by the U.S. Tax Court in Consolidated Premium Iron Ores Ltd. v. C.I.R. ${ }^{99}$

On the other hand, a place that could be characterized as a "place of business" under the Canada-U.S. Convention is a home office; in other words, a separate office established in a dwelling. A German court decision is persuasive in this respect. ${ }^{100}$ There, the Court held that the dwelling of a midwife was a "place of business" and thus PE-constituting, because "the house contained the facilities where she received pregnant women for counselling. In this case, the separate rooms in the house were considered crucial for the taxpayer's business activities...." ${ }^{101}$ Since the dwelling was used as a "place of business," it was held to be PE-constituting.

\section{The Location Test}

The objective presence test also requires the place of business to be located at a specific place because it must be "fixed" under article V(1) of the Canada-U.S. Convention. Traditionally, it was felt that for the "location test" to be met, the place of business had to be fixed to the soil. However, international courts have expanded this test over a number of years to include movable places of business that have a link to a specific geographical point. ${ }^{102}$ For example, a decision of the German lower tax court $^{103}$ involved a market vendor who was a resident of The Netherlands and operated in Germany. Each week, the vendor set up a sales stand in three markets, each located

Technical Explanation, supra note 82 at 1.

Skaar, supra note 33 at 121 .

(1972), 72 D.T.C. 6288 (S.C.C.) [hereinafter Tara]. Although this case did not concem a double taxation treaty between Canada and the U.S., it is persuasive law under the 1980 Canada-U.S. Convention, especially given that a Canadian court interpreted the PE provisions of the treaty in question.

28 T.C. 127 (Tax Ct. 1957) [hereinafter Iron Ore].

Finanzgericht Schleswig-Holstein in EFG 1963, at 398; referred to in Skaar, supra note 33 at 203. Skaar, ibid.

Ibid. at 127, 148; see also 1977 OECD Model Treaty, Commentary on art. V(1), supra note 34 at 60.

Finanzgericht Munster ["Market Vendor"], in EFG 1966 at 501; referred to in Skaar, ibid. at 12627. 
in different towns in Germany. The Tax Court held that the taxpayer's sales stand constituted a PE in Germany because it was located on the same spot within the same three markets each week, and thus constituted a centre for his business activities. This case has not specifically been adopted in Canada or the U.S. but it is persuasive in the interpretation of the basic rule for PE under the Canada-U.S. Convention.

In addition, stationary, floating business activities, such as permanent offshore petroleum installations or drilling rigs, have been considered to be located at a specific place, and therefore, PE-constituting. This was confirmed in a decision of the Norwegian tax authorities. ${ }^{104}$ A Swedish company operated a floating platform which moved between several permanent installations located in the Norwegian sector of the North Sea. Although this platform was mobile and was not fixed to any part of the soil, the tax authorities still found that the "location test" was met because the platform was located within a specific geographical area. This case has been specifically adopted under article V(4) of the Canada-U.S. Convention which states that "[t]he use of a drilling rig or ship in a Contracting State to explore for or exploit natural resources constitutes a $[\mathrm{PE}] . . . . "$

\section{B. THE SUBJECTIVE PRESENCE OF THE PE}

Under the subjectivity of the PE, there must be a right to use the "fixed place of business" accruing to the non-resident taxpayer and this right of use must be permanent.

\section{The Right of Use Test}

Under the 1977 OECD Model Treaty, it is not necessary that the non-resident taxpayer has a legal right of use to a place of business; for example, through ownership or lease. Also, the taxpayer does not have to have an exclusive right to use the place of business to meet the right of use test. Rather, access to the premises need only be at the taxpayer's constant disposal. ${ }^{105}$ As concluded by Skaar, "the 'right of use test' is met if the taxpayer's use of the place of business cannot be prevented without his consent."106

The Canada-U.S. Convention does not specify the circumstances which indicate when a non-resident taxpayer would have a right to use a place of business. However, this can be determined by examining Canadian and American judicial decisions which interpret the basic rule for PE under the 1942 and 1980 Canada-U.S. Conventions. For example, the Court in Johnston v. C.I.R. ${ }^{107}$ examined whether a general partner of a business had a right to use another partner's place of business, and consequently whether he had a PE in this place of business. The taxpayer Johnston was a resident

Hotel Platform, letter from the Norwegian Directorate of Taxes to local tax authorities (6 June 1980); referred to in Skaar, ibid. at 139.

Skaar, ibid. at 157; see 1977 OECD Model Treaty, Commentary on art. V(1), supra note 34 at 59 60.

Skaar, ibid. at 158.

24 T.C. 920 (Tax Ct. 1955) [hereinafter Johnston]. 
of Canada. He entered into an agreement with a U.S. partnership whereby he was to purchase cattle in Canada and ship the cattle to the U.S. in the name of the U.S. partnership. The U.S. partnership, in turn, was to resell the cattle in the U.S. Any profits or losses from the sale of the cattle were to be shared equally between Johnston and the U.S. partnership. Since the U.S. Tax Court found the relationship between the taxpayer and the U.S. partnership to be a partnership for U.S. tax purposes, it was held that the taxpayer had a PE in the U.S. This is because the U.S. partnership was a place of business and because the taxpayer had a right to use the place of business to conduct business activities. As a result, the taxpayer was taxable by the U.S.

Whether or not a limited partner, as opposed to a general partner, ${ }^{108}$ has a right to use the partnership's place of business is not as clear because limited partners do not themselves organize or participate in any business activities, unlike general partners. This issue was discussed in Unger v. C.I.R. ${ }^{109}$ Unger considered whether or not a Canadian dentist was taxable by the U.S. for his share of a limited partnership's income. The limited partnership was in the business of constructing and managing residential housing in Massachusetts and it consisted of twenty-two limited partners, of which the taxpayer was one, and seven general partners. The Court concluded that the taxpayer had a PE in the U.S. because the partnership was found to be a place of business over which the taxpayer had a right of use. Thus, it appears from this decision that in the case of partnerships, a taxpayer has a right to use that partnership by virtue of being a partner, whether he or she is a general or a limited partner.

Another issue under this test is whether or not a taxpayer can be said to have a right of use of an unrelated company's facilities under the PE definition. In a decision by the German tax authorities, ${ }^{110}$ it was held that a foreign corporation's long-term use of a client's premises in Germany met the right of use test even though the taxpayer did not have a legal right to use these premises. This case is persuasive in the interpretation of the basic rule for PE under the Canada-U.S. Convention.

In addition to evidence of partnership or long-term use of a client's premises, other evidence can also be examined to determine if a taxpayer has a right to use a place of business. Such evidence may consist of licences, stationery, letterheads, firm signs, bank accounts and so on. For example, in Iron Ore,"' a Canadian company obtained a licence to sell iron ore in the U.S. and conducted various other activities preparatory to setting up operations in the U.S. The company, however, did not form any organization in the U.S., nor did it conduct any business under the licence. Although

"A limited partnership consists of both general and limited partners. The limited partners contribute capital and share in profits, but are not bound by the obligations of the partnership beyond their contribution. Normally, they will not be directly engaged in the business of the partnership. The general partners, however, have unlimited responsibility for the partnership's obligations. They are often engaged in the day-to-day business of the partnership." (Skaar, supra note 33 at 170 ). 58 T.C.M. 1157 (Tax Ct. 1990) [hereinafter Unger]. Letter from Central Office Foreign Tax Affairs to the taxpayer's accountant (1 August 1989); referred to in Skaar, supra note 33 at 188-89.

Supra note 99. 
the license was evidence of a right to use a place of business, the Court held that a PE did not exist solely by virtue of the licence. It stated:

The term "permanent establishment" normally interpreted suggests something more substantial than a license, a letterhead, and isolated activities. It implies the existence of an office, staffed and capable of carrying on the day-to-day business of the corporation and its use for such purpose, or it suggests the existence of a plant or facilities equipped to carry on the ordinary routine of such business activity. ${ }^{112}$

Thus, to have a right of use to a place of business, the right must consist of something "substantial."

A final issue under the "right of use test" is whether a franchisor has a right to use a franchisee's place of business. Skaar concludes that where a franchisor acts like a partner of the franchisee, in that it receives a share of the franchise's gross or net earnings and has substantial influence on the business decisions of the franchise, the right of use test may be met. ${ }^{113}$ "However, [where] the franchisor's income is solely based on [the franchisor's] prices to the franchisee ... [for example, where] the profits of the franchisor are not directly linked to the profits of the franchisee in a jointventure-like manner..., ${ }^{1114}$ then the right of use test will not be satisfied.

\section{The Permanence Test}

Because the place of business has to be permanent or "fixed" under article V(1) of the Canada-U.S. Convention, Skaar states that the right to use the place of business must also be permanent. Under international case law, however, the requirement of "permanence" is not taken literally. The right of use does not have to be forever; rather, it simply has to be of a long duration. ${ }^{115}$

The issue under this test is what length of time is considered sufficient to meet the "permanence test." To determine a sufficient length of time, other clauses under the PE provisions of the Canada-U.S. Convention may be persuasive. For example, under article V(3) of the Convention, "[a] building site or construction or installation project constitutes a permanent establishment if, but only if, it lasts more than 12 months." 116 Whether or not this twelve month period is sufficient to meet the "permanence test" under the basic rule for PE is debatable. Skaar argues that since this clause is separated from the basic rule for $P E$ in article $V(1)$, this indicates that the twelve month duration does not apply to the basic rule for PE. ${ }^{117}$ In addition, several international judicial decisions support this conclusion and indicate that a shorter time period may be

Ibid. at 152.

Supra note 33 at 193-94.

Ibid.

Henriksen (Inspector of Taxes) v. Grafton Hotel, Ltd., [1942] 2 K.B. 184 at 196 (C.A.); referred to in Skaar, ibid. at 210.

This is not considered part of the basic rule for PE. Rather, this is a deemed PE and is subject to other tests which are outside the scope of this article; see Skaar, ibid. at 343-419.

Skaar, ibid. at 216-17. 
sufficient. ${ }^{118}$ Thus, a taxpayer's right to use a place of business for more than twelve months may not be required for it to be PE-constituting under the basic rule.

There are several cases decided by Canadian courts which support a shorter duration than twelve months, but are unclear as to what should be considered a "long duration" under the "permanence test." For example, in Shahmoon, ${ }^{119}$ the Court held that a business activity which was conducted in Canada for a period of one to two months every year for a number of years did not satisfy the "permanence test." However, in Fowler v. M.N.R. ${ }^{120}$ the Tax Court of Canada held that the taxpayer, a resident of the U.S., who conducted sales activities at a collapsible booth at the Pacific National Exhibition in Vancouver, Canada for three weeks out of every year for the preceding fifteen years, satisfied the "permanence test."121 Clearly, three weeks is not of a "long duration." However, a permanent right of use was still found because of the many years that this "temporary" business activity was operated. Canadian tax authorities have also stated that "permanence" is a relative term depending on the circumstances of each case. For example, "[s]hort summer seasons in northern Canada ... allow a shorter duration for 'permanence'...."122 Canadian tax theory has also argued that the basic rule for PE does not require a minimum duration such as twelve months. ${ }^{123}$

U.S. practice, on the other hand, seems to be much stricter than Canadian practice with respect to the "permanence test." In several administrative rulings, a duration of up to five months was held not to meet the "permanence test." 124 Instead, a much longer duration appears to be favoured in U.S. judicial decisions. For example, in Johnston, ${ }^{125}$ the Court held that because the taxpayer pursued his business activity in the U.S. for two years, the basic rule for PE was satisfied. The preference of a longer duration for the "permanence test" is also supported in correspondence concerning a U.S. tax treaty which argued in favour of extending the twelve month rule to the basic rule for PE. ${ }^{126}$

The conflicting Canadian and American jurisprudence shows that it is not exactly clear how long a taxpayer must have a right to use a place of business for the

See e.g. the decision (5 December 1974), no. 161/72 Ml (Lower Ct. of Amsterdam), cited in Skaar, ibid. at 215.

119 Supra note 65.

120 (1990), 90 D.T.C. 1834 (T.C.C.).

121 The "location test" mentioned earlier in this article was also satisfied in the case, despite the fact that the booth was not fixed to the soil. Thus, a PE was found to exist.

122 Skaar, supra note 33 at 220 , referring to an interview with representatives of the Department of Finance and Revenue Canada (May 1988).

123 Nitikman, supra note 95 at 166, cited in Skaar, ibid. at 220.

124 Letter of U.S. Treasury to Luxembourg tax authorities (14 May 1964), concerning the interpretation of the "permanence test" of the basic rule of DTA USA-Luxembourg 1962; referred to in Skaar, ibid. at 221. See also U.S. Drilling Rig, Ltr. Rul. 85-26-005; referred to in Skaar, ibid. Supra note 107.

125 Letter of May 14, 1964, supra note 124; and Letter from the Luxembourg Office of the Director of Direct Taxes and Excises to U.S. Treasury (22 May 1964); referred to in Skaar, supra note 33 at 215 . 
"permanence" test to be met. This is so even when such jurisprudence concerns a Canada-U.S. Convention. Skaar, however, suggests that one must look at the objective and subjective intention of the taxpayer as well as all of the circumstances surrounding each case; for example, did the taxpayer intend the place of business to be permanent and is it clear from the facts that the place of business will last for a substantial period of time? ${ }^{27}$ It is only by examining these questions that the requirement of permanence under the Canada-U.S. Convention may be resolved.

\section{THE FUNCTIONALITY OF THE PE}

The final two tests that must be met before a PE will be found to exist are as follows: the non-resident taxpayer must conduct "business" activities and these business activities must be conducted through the place of business.

\section{The Business Activities Test}

According to Skaar, the activities of the taxpayer must be "business" activities and not just "income-generating" activities for the PE provisions to be satisfied. ${ }^{128}$ The term "business" is not defined under the Canada-U.S. Convention. Thus, under article II(2) of the Convention, the meaning which this undefined term has under the domestic laws of the Contracting States can be examined. ${ }^{129}$

The term "business" is not explicitly defined in the U.S. Internal Revenue Code. ${ }^{130}$ Therefore, American judicial practice must be reviewed. The Court in C.I.R v. Groetzinger ${ }^{131}$ held that for a taxpayer to be engaged in a business, "the taxpayer must be involved in the activity with continuity and regularity with the primary purpose of making a profit."132 Further, in C.I.R. v. Nubar, ${ }^{133}$ it was held that the taxpayer was engaged in business activities because he was involved extensively in the trading of stocks and commodities. In Canadian law, "business" is also left undefined in the Income Tax Act. ${ }^{134}$ The case law seems to suggest, however, that where a taxpayer spends all of his or her time and effort to obtain profits from the activity and becomes an expert at the activity, he or she may be engaged in "business" activities. ${ }^{135}$

These types of activities are contrasted with income-generating activities which do not involve extensive activity on the part of the taxpayer. Rather, the taxpayer remains relatively passive and simply collects income from the revenue-producing property. In addition, with such "income-generating activities," the taxpayer is usually not a trader

Skaar, ibid. at 218; see also 1977 OECD Model Treaty, Commentary on art V(1), supra note 34 at 60 .

Skaar, ibid. at 245.

See also other sources of tax treaty interpretation mentioned earlier in this article that allow this. Supra note 19; see also Skaar, supra note 33 at 246.

107 S. Ct. 980 (1987); referred to in Skaar, ibid. at 247 [hereinafter Groetzinger].

Skaar, ibid., referring to Groetzinger, ibid.

185 F.2d 584 (4th Cir. 1950).

Supra note 11.

R. v. Balanko, [1988] 1 C.T.C. 317 (F.C.T.D.). 
in a particular type of an asset; rather, the taxpayer holds that asset for a long term to produce revenue. This is illustrated in Masri v. M.N.R. ${ }^{136}$ In that case, the Canadian Court held that there was no PE where the taxpayer, a U.S. resident, simply bought and sold land in Canada and made substantial profits. This activity was found to be a sideline activity of the taxpayer, conducted merely for the purpose of income generation, and was not a "business" activity. The taxpayer was found not to be in the business of buying and selling land. The same was also found in Tara, ${ }^{137}$ where the Supreme Court of Canada stated that there was no PE because the management of investment income from selling securities had not reached a high enough level to constitute a business.

Thus, it appears that "business" activities in contrast to "income-generating" activities involve elements of continuity, constant repetition and regularity. Where these are found, the "business activities test" will be satisfied.

It should be noted that under article V(6) of the Canada-U.S. Convention, certain business activities are excluded as being PE-constituting where these are the sole activities engaged in by the taxpayer. ${ }^{138}$ Further, article $V(6)(e)$ of the Convention refers to "similar activities which have a preparatory or auxiliary character...." Thus, it appears that any activity with such a character will not pass the "business activities test." For example, in Iron Ore, ${ }^{139}$ the Canadian Court held that a Canadian enterprise which conducted "missionary work" to obtain commitments from steel companies in the U.S. to buy iron ore was merely conducting preparatory activities. A PE was held not to exist.

Under the 1977 OECD Model Treaty, an activity will not be considered to be of a preparatory or auxiliary nature where the activity "forms an essential and significant part of the activity as a whole." ${ }^{140}$ Also, according to Skaar, "[i]f an ... activity [that is excluded under article V(6) of the Convention] is combined with a core business activity [and] performed through the same place of business, a PE is created." ${ }^{141}$ It is clear that one must look at the general purpose of the enterprise and the activity's relative importance to the whole enterprise to determine whether or not the conducted activity satisfies the "business activities test."

\footnotetext{
136 [1973] C.T.C. 448 (F.C.T.D.).

137 Supra note 98.

138 These activities include:
}

(a) The use of facilities for the purpose of storage, display or delivery of goods or merchandise belonging to the resident; (b) The maintenance of a stock of goods or merchandise belonging to the resident for the purpose of storage, display or delivery; (c) The maintenance of a stock of goods or merchandise belonging to the resident for the purpose of processing by another person; (d) The purchase of goods or merchandise, or the collection of information, for the resident; and (e) Advertising, the supply of information, scientific research or similar activities which have a preparatory or auxiliary character, for the resident.

160 1977 OECD Model Treaty, Commentary on art. V(4), supra note 34 at 64.

141 Supra note 33 at 280. 


\section{The Business Connection Test}

Article V(1) of the Canada-U.S. Convention states that a PE is a "fixed place of business through which the business of a resident of a Contracting State is wholly or partly carried on." 142 According to Skaar, this means that the business activity of the taxpayer must be conducted through the place of business. In other words, there must be a sufficient connection between the business activity and the place of business for a PE to exist. ${ }^{143}$

For example, in Tara, ${ }^{144}$ a company was a resident of Ireland for treaty purposes because its management resided in Ireland. The company established an office in Canada because the company was also incorporated in Canada. The Court found that the sole reason for the establishment of this office in Canada was to comply with the requirements of Canadian tax laws. It held that any profit-making activity of the company was not conducted through the office, and thus, the office did not constitute a PE under the treaty in question. Although this case did not involve the Canada-U.S. Convention, it is persuasive in determining the make up of the "business connection test."

\section{TAX PLANNING CONSIDERATIONS - BRANCH OPERATIONS OR A SUBSIDIARY?}

It is important that the foregoing be considered by any Canadian or American taxpayer to understand the various tax planning opportunities available in international business. For example, a number of alternatives are available to a person, whether a corporation or an individual, who is a resident of the United States and wishes to directly invest in the Canadian market. This example will be used to evaluate the advantages and disadvantages of setting up a permanent establishment in Canada, namely through branch operations, as opposed to setting up a subsidiary in Canada. The example is based on the assumption that if a PE is established, all of the tests outlined in this article concerning the basic rule for PE have been satisfied.

A branch operation differs from a subsidiary in that it is not incorporated in Canada as a separate business from the U.S. head office to carry on business in Canada. Rather, it remains a part of the business of the head office but is located in Canada. ${ }^{145}$ An American person may prefer to use branch operations in Canada as opposed to a subsidiary for a number of reasons. A branch may be more favourable where an American corporation or individual lacks experience in the Canadian market. ${ }^{146}$ In addition, particularly in petroleum-related industries where the operations in Canada are

[Emphasis added].

Skaar, supra note 33 at 327.

Supra note 98.

W.J.A. Mitchell \& J.M. Monohan, "Investment by U.S. Residents in Canada" in Canada-U.S. Tax Treaty - Materials Prepared for a Continuing Legal Education Seminar held in Vancouver, B.C. on February 16, 1985 (Vancouver: The Continuing Legal Education Society of British Columbia, 1985) at 4.1.01.

Skaar, supra note 33 at 8-9. 
not intended to be of an indefinite duration, it may not be useful to incorporate in Canada for a limited period of time. ${ }^{147}$ Finally, there may be tax reasons favouring branch operations over a subsidiary.

The first tax reason favouring branch operations is the payment of a lower amount of tax. For example, under the Canadian Income Tax Act, the earnings of a subsidiary in Canada are essentially taxed twice. The subsidiary itself is required to pay tax on its income under Part I of the Income Tax Act, and non-resident shareholders - for example, the parent corporation - are required to pay withholding tax on dividends paid by the subsidiary, under Part XIII of the Income Tax Act. ${ }^{148}$ With branch operations, this Part XIII tax is not paid because a branch cannot legally distribute dividends since it is not an incorporated body and does not have shareholders. ${ }^{149} \mathrm{~A}$ second tax reason favouring branch operations is that fewer categories of the branch's income are considered taxable. A Canadian subsidiary, since it is considered to be a Canadian resident under s.250(4) of the Income Tax Act, is taxed not only on its Canadian-sourced income but also on all of its worldwide income by virtue of section 2(1) of the Act. A Canadian branch, on the other hand, is only taxed on its Canadiansourced income under articles V and VII of the Canada-U.S. Convention. A final tax reason favouring the establishment of a branch in Canada is as follows: where the branch is of such a temporary or transient nature so as to avoid the creation of a PE under article V of the Canada-U.S. Convention, the profits of the PE will not be subject to any Canadian tax. ${ }^{150}$

Branch operations in Canada can be disadvantageous in comparison to Canadian subsidiaries, however. For example, the business profits of the branch are subject to a branch profits tax under Part XIV of the Canadian Income Tax Act. ${ }^{151}$ In addition, branch operations in Canada do not permit the deferral of payment of U.S. tax by the parent corporation on profitable Canadian operations, whereas the establishment of a Canadian subsidiary will permit this. ${ }^{152}$ There may also be non-tax reasons for preferring a subsidiary over branch operations where the Canadian operation is of any significant size. For example, the parent corporation, as a shareholder in the subsidiary, would enjoy limited liability for the subsidiary under section 45 of the Canadian Business Corporations Act. ${ }^{153}$ Also, the Canadian subsidiary does not have to pay

Ibid.

Under the Income Tax Act, this withholding tax is 25 percent. This has been reduced under the Canada-U.S. Convention to 15 percent on portfolio dividends (article $\mathrm{X}(2)(\mathrm{b})$ ) and 10 percent on dividends where the U.S. parent owns 10 percent or more of the voting shares of the Canadian subsidiary (article $X(2)(a)$ ).

Mitchell \& Monohan, supra note 145.

Ibid. at 4.1.06 and 4.1.10. This is because under article VII of the Convention, the business profits of the branch are only taxable by Canada if the branch is found to be a PE in Canada.

The purpose of this tax is "to neutralize for tax purposes the carrying on of business in Canada through a branch or a subsidiary." (ibid. at 4.1.01). Note, however, that the branch may also be eligible for a direct foreign tax credit under the Canadian Income Tax Act, supra note 11, s. 126. Mitchell \& Monohan, ibid. at 4.1.10.

R.S.C. 1985 , c. C-44; see also ibid. 
out all of its profits to shareholders as dividends, whereas all of the profits of a branch operation automatically revert back to the U.S. corporation. ${ }^{154}$

It appears that there are various tax and non-tax advantages to setting up a branch operation in Canada as opposed to a Canadian subsidiary. Such tax planning opportunities are available because of the Canada-U.S. Convention and should be considered by any American person wishing to conduct business in Canada.

\section{CONCLUSION: ADEQUACY OF THE PE PROVISIONS IN THE ELIMINATION OF DOUBLE TAXATION}

The PE concept has several implications for the conduct of international business, particularly with respect to business conducted between Canada and the U.S. For instance, article $\mathrm{V}$ of the Canada-U.S. Convention is an effective way of allocating taxing jurisdiction between Canada and the U.S. over a resident of one of the Contracting States who is conducting unincorporated business activities in the other Contracting State. First, the PE concept closes a tax loophole in that it prevents a person from setting up operations in the other Contracting State simply to avoid being taxed on its income from those operations. This is important to ensure that a Contracting State receives tax revenues to which it is rightly entitled in order to provide for the social needs of its citizens. Second, the PE concept is effective in preventing the incidence of double taxation. Where a Canadian resident sets up a branch operation in the U.S., for example, that branch can only be taxed by the country in which its income is earned; namely, the U.S. Canada cannot also tax the income of the branch operation by virtue of the branch's status as a resident of Canada. Third, in preventing double taxation, the PE provisions encourage investment in each country by the other and permit the free movement of capital, people and services between Canada and the U.S. This is necessary given the free trade relationship between the two states in the last decade. Finally, the PE concept plays an important part in the tax planning of a corporation or an individual who wishes to conduct business internationally. For example, by having a knowledge of the governing international tax rules, a U.S. corporation can plan in advance whether it is more advantageous to set up a branch operation or a subsidiary in Canada.

On the other hand, the PE concept is disadvantageous as a means of allocating taxing jurisdiction in several respects. First, although the tests outlined in this article are detailed enough to determine the existence of a PE, some of the tests are not adequately or consistently defined for the purposes of the Canada-U.S. Convention. For example, the "location" test is unclear as to whether the place of business has to be fixed to a specific part of the soil or whether the place of business can be moved around within a specific geographical area. The case law and the Convention itself seem to suggest that the latter is a more appropriate way of reflecting modern modes of conducting business, but are not decisive on the matter. In addition, the "permanence" test is extremely unclear. The applicable case law has not conclusively determined how long 
the taxpayer must have a right to use the place of business for it to be considered "permanent."

Second, application of the basic rule for PE does not always lead to predictable results. This is because the language in the Canada-U.S. Convention is very general and is interpreted by two very different bodies of law. For this reason, the PE provisions under the Canada-U.S. Convention must be modified to reflect Canadian, American and persuasive international case law and developments concerning permanent establishments. One way to promote consistency in the interpretation of the PE provisions is to make the Technical Explanation under the Canada-U.S. Convention more detailed by outlining the tests and the interpretations thereof to determine the existence of a PE. This may, however, make the PE provisions too specific and less flexible in reflecting future developments. Another method would be to change the definition of PE in the Convention itself to reflect judicial interpretation. This may also be problematic, however, because of the major difficulties encountered in amending any treaty, such as the conflicting interests and desires of the Contracting Parties. ${ }^{155}$ Such a proposal would, problematically, raise the further issue of whether such amendments should reflect international judicial interpretation as well as Canadian and American judicial interpretation, or solely the latter bodies of law.

Third, the PE provisions under the Canada-U.S. Convention do not close all the tax loopholes. For example, a person can avoid establishing a PE simply by conducting the activities exempted under article V(6) of the Convention or by establishing operations for a very short period of time, thereby not coming within the tests for a PE. This problem also might be addressed by amending the Convention. Canada and the U.S. are currently in the process of negotiations to amend the Convention, but no lasting agreements have yet been reached. ${ }^{156}$ This reflects the difficult nature of the treaty formulation process.

Despite the problems with the PE provisions of the Canada-U.S. Convention, it is clear that the PE concept has improved the free movement of goods, services and persons between Canada and the U.S. This is consistent with the trend towards the internationalization of the two economies. By examining the sources of interpretation outlined in this article, it is possible to see how the PE concept will serve to further improve economic relations between Canada and the U.S. and the rest of the world. 